\title{
Genetic polymorphisms in the renin-angiotensin system: relevance for susceptibility to cardiovascular disease
}

\author{
Ji-Guang Wang, Jan A. Staessen* \\ Study Coordinating Centre, Hypertension and Cardiovascular Rehabilitation Unit, Department of Molecular and Cardiovascular Research, \\ University of Leuven, Leuven, Belgium
}

Accepted 20 October 2000

\begin{abstract}
The renin-angiotensin system plays an important role in the pathogenesis of cardiovascular disease. Cloning of the human genes coding for the angiotensin-converting enzyme, angiotensinogen, and angiotensin II type 1 receptor has led to the discovery of several polymorphisms, which may be implicated in the pathogenesis of cardiovascular disease. The deletion/insertion $(D / I)$ polymorphism of the angiotensin-converting enzyme gene is associated with hypertension in men, left ventricular hypertrophy in untreated hypertensive patients, various atherosclerotic cardiovascular complications, and microvascular disorders. The M235T polymorphism of the angiotensinogen gene may be associated with a higher risk of hypertension. The A1166C polymorphism of the angiotensin II type 1 receptor gene is probably correlated with hypertension and through an epistatic interaction with the $D / I$ polymorphism of the angiotensin-converting enzyme gene possibly also with coronary heart disease. Several other gene polymorphisms, in particular those in the promoter area of the angiotensinogen gene, have been studied in relation to cardiovascular disease. Based on the insights gained from the reports summarized in this review article, population-based genetic studies of nuclear families are currently being conducted in Belgium and in the People's Republic of China with blood pressure and hypertension as the main outcome variables. C) 2000 Elsevier Science B.V. All rights reserved.
\end{abstract}

Keywords: Gene polymorphism; Susceptibility; Cardiovascular disease; Angiotensin-converting enzyme; Angiotensinogen; Angiotensin II type 1 receptor

\section{Introduction}

The renin-angiotensin system, a two-enzyme cascade, plays an important role in the regulation of blood pressure, fluid balance, and electrolyte homeostasis (Sealey et al., 1995; Hall et al., 1986) and in the pathogenesis of cardiovascular disease (Dzau, 1993; Campbell, 1987). The initial enzyme, renin, cleaves its substrate, angiotensinogen, to angiotensin I, a decapeptide. Angiotensin I undergoes a second cleavage, mainly by tissue-bound angiotensin-converting enzyme and serine proteinase (Urata et al., 1996), to generate angiotensin II (an octapeptide), which via the angiotensin II type 1 receptor acts as a potent vasocon-

\footnotetext{
* Corresponding author. Studiecoördinatiecentrum, Inwendige Geneeskunde-Cardiologie, Klinisch Laboratorium Hypertensie, Gebouw Onderwijs en Navorsing, Campus Gasthuisberg, Herestraat 49, B-3000 Leuven, Belgium. Tel.: +32-16-34-71-04 (office), +32-15-41-17-47 (home); fax: +32-16-34-71-06 (office), +32-16-34-57-63 (office), +3215-41-45-42 (home).

E-mail address: jan.staessen@med.kuleuven.ac.be (J.A. Staessen).
}

strictor and aldosterone stimulating peptide. The angiotensin-converting enzyme also inactivates the nonapeptide bradykinin and blocks the tissue kallikrein system. Inhibition of the angiotensin-converting enzyme and antagonism of the angiotensin II type 1 receptor decrease blood pressure in hypertensive patients (MacKay et al., 1996; Azizi et al., 1997), and more importantly also prevent mortality and morbidity in patients with symptomatic or asymptomatic congestive heart failure (Sharpe et al., 1988, 1991; Pfeffer et al., 1992), acute myocardial infarction (ACE Inhibitor Myocardial Infarction Collaborative Group, 1998), or diabetic nephropathy (Lewis et al., 1993).

Cloning of the human genes coding for the angiotensin-converting enzyme (Rigat et al., 1990, 1992), angiotensinogen (Jeunemaitre et al., 1992), and the angiotensin II type 1 receptor (Bonnardeaux et al., 1994) has led to the discovery of several polymorphisms (Table 1), which may play a role as risk factors for cardiovascular disorders, such as hypertension, coronary heart disease, or cardiomyopathy. Among these genetic mutations, the angiotensin-converting enzyme gene deletion/insertion $(D /$ 
Table 1

Polymorphisms of genes coding for the proteins of the renin-angiotensin system

\begin{tabular}{|c|c|c|c|c|c|}
\hline $\begin{array}{l}\text { Gene (cytogenetic } \\
\text { map location) }\end{array}$ & Polymorphism & $\begin{array}{l}\text { Location } \\
\text { in gene }\end{array}$ & Change in DNA & Change in protein & Reference \\
\hline $\begin{array}{l}\text { Angiotensin-converting } \\
\text { enzyme (17q22-q24) }\end{array}$ & $D / I$ & intron 16 & $\begin{array}{l}287 \mathrm{bp} \\
\text { deletion } \rightarrow \text { insertion }\end{array}$ & concentration & (Rigat et al., 1990) \\
\hline \multirow{3}{*}{$\begin{array}{l}\text { Angiotensinogen } \\
(1 \mathrm{q} 42-\mathrm{q} 43)\end{array}$} & $A-20 C$ & promoter & $\mathrm{A} \rightarrow \mathrm{C}$ & concentration & (Ishigami et al., 1997) \\
\hline & $C-18 T$ & promoter & $\mathrm{C} \rightarrow \mathrm{T}$ & concentration & (Sato et al., 1997) \\
\hline & $M 235 T$ & exon $2(+704)$ & $\mathrm{T} \rightarrow \mathrm{C}$ & methionine $\rightarrow$ threonine & (Jeunemaitre et al., 1992) \\
\hline \multirow{2}{*}{$\begin{array}{l}\text { Angiotensin II type } 1 \\
\text { receptor (3q21-q25) }\end{array}$} & $T-810 A$ & promoter & $\mathrm{T} \rightarrow \mathrm{A}$ & $?$ & (Poirier et al., 1998) \\
\hline & $A 1166 C$ & $3^{\prime} \mathrm{UTR}$ & $\mathrm{A} \rightarrow \mathrm{C}$ & receptor sensitivity & (Bonnardeaux et al., 1994) \\
\hline
\end{tabular}

I) (Staessen et al., 1997b), angiotensinogen gene M235T (Staessen et al., 1999), and the angiotensin II type 1 receptor gene A1166C (Bonnardeaux et al., 1994) polymorphisms have been extensively investigated in various populations with a variety of cardiovascular disorders. Several other polymorphisms, in particular in the promoter region of the angiotensinogen gene, were also found to be associated with cardiovascular disease (Villard et al., 1996; Ishigami et al., 1997; Sato et al., 1997; Inoue et al., 1997; Jeunemaitre et al., 1992; Poirier et al., 1998). This review summarizes the findings on the associations between these genetic polymophisms and cardiovascular disease.

\section{2. $D / I$ polymorphism of the angiotensin-converting enzyme gene}

The $D / I$ polymorphism consists of either the absence or presence of a 287 base-pair DNA fragment, in intron 16 of the angiotensin-converting enzyme gene. It has been shown to predict approximately half of the inter-individual variability in the serum (Rigat et al., 1990; Tiret et al., 1992) and tissue (Danser et al., 1995) levels of the angiotensin-converting enzyme. Compared with the II genotype, the angiotensin-converting enzyme activity was highest in $D D$ homozygotes and intermediate in $I D$ heterozygotes. Numerous studies have investigated the relationships between the angiotensin-converting enzyme gene variants and several cardiovascular-renal disorders, such as hypertension, myocardial infarction, hypertrophic cardiomyopathy, and diabetic or non-diabetic nephropathy.

\subsection{Prevalence of $D$ allele}

According to a meta-analysis (Staessen et al., 1997b) of 145 studies (available in June 1997) on the $D / I$ polymorphism of the angiotensin-converting enzyme gene, the overall prevalence of the $D$ allele in 49,959 subjects amounted to $54.0 \%$. The $D D, D I$ and II genotype frequencies were $30.5 \%, 47.0 \%$ and $22.5 \%$, respectively.
Race was a major determinant of the $D$ and $I$ allele frequencies. The prevalence of the $D$ allele was $56.2 \%$ in Caucasians, higher $(P<0.001)$ in blacks $(60.3 \%)$, but substantially lower $(P<0.001)$ in Asians $(39.1 \%)$.

\section{2. $D$ allele and cardiovascular disease}

\subsubsection{Hypertension}

In the above-mentioned meta-analysis (Staessen et al., 1997b), 23 case-control studies were combined. Hypertension or having a family history of hypertension were not significantly associated with the $D$ allele. However, there was a significant heterogeneity among the reports. Compared with the II genotype, $D D$ homozygozity was associated with a $79 \%$ and $61 \%$ higher risk of hypertension in two studies in women (Gu et al., 1994; Kiema et al., 1996) and in two Japanese (Higashimori et al., 1993; Morise et al., 1994) combined with one Chinese (Jian et al., 1996) report, respectively. In all other subgroups, the association between hypertension and the angiotensin-converting enzyme genotype was not statistically significant. Systolic and diastolic blood pressure data were available in 46 studies (Staessen et al., 1997b). In all 12,230 subjects (74 groups) and in the subgroup analyses, the blood pressure levels showed only small and non-significant variations according to the genotype.

However, two recent population studies (O'Donnell et al., 1998; Higaki et al., 2000) found that the $D$ allele was significantly associated with hypertension in men but not in women. In 3095 Framingham Heart Study participants (O'Donnell et al., 1998), the adjusted odds ratios for hypertension were 1.59 (95\% confidence interval [CI] $1.13-2.23)$ and 1.18 (95\% CI $0.87-1.62)$ for $D D$ and $D I$ subjects as compared with II homozygotes in men, whereas in women the corresponding odds ratios were not significant. Among 5014 Japanese residents of the city of Suita (Higaki et al., 2000), the frequency of $D D$ homozygosity was higher in hypertensive men than in their mildly hypertensive or normotensive counterparts $(17.1 \%$ vs. $11.8 \%$; $P<0.002)$, and the estimated odds ratio for hypertension ( $D D$ vs. $I I)$ was 1.75 (95\% CI 1.21-2.53). The corre- 
sponding odds ratio in women was only $1.17(95 \% \mathrm{CI}$ $0.79-1.72)$.

\subsubsection{Diseases of myocardium}

The $D$ allele was also found to be associated with higher risk of electrocardiographic (Schunkert et al., 1994) or echocardiographic left ventricular hypertrophy (Gharavi et al., 1996), hypertrophic cardiomyopathy (Marian et al., 1993) and idiopathic (Raynolds et al., 1993) or ischemic (Raynolds et al., 1993) dilated cardiomyopathy. However, in a meta-analysis (Staessen et al., 1997b), the overall excess risk of these diseases in relation to the $D$ allele was not significant.

A further meta-analysis (Kuznetsova et al., 2000) specifically derived pooled estimates for the association between electrocardiographic or echocardiographic left ventricular hypertrophy and the $D / I$ polymorphism of the angiotensin-converting enzyme gene. The study included 28 reports with an overall sample size of 6638 subjects. In all studies combined, left ventricular hypertrophy was not associated with the $D$ allele. Compared with the II genotype, the excess risks of left ventricular hypertrophy associated with $D D$ and $D I$ genotypes were only $14 \%$ (95\% CI $0.92-1.42 ; P=0.23)$ and $5 \%(95 \%$ CI $0.87-1.28$; $P=0.61$ ), respectively. However, the sensitivity analysis showed that in untreated hypertensive patients the $D D$ genotype, compared with II homozygosity, was associated with a $192 \%(P=0.002)$ higher risk of left ventricular hypertrophy (Kuznetsova et al., 2000). Furthermore, if left ventricular mass was analyzed as a continuous trait across 23 studies (5438 subjects), overall no association with the $D / I$ polymorphism was present. However, if untreated hypertensive patients (Iwai et al., 1994a,b; Gharavi et al., 1996; Pontremoli et al., 1996) were analyzed separately, echocardiographic left ventricular mass was on average $10.1 \%$ (95 CI 4.8-15.5\%; $P=0.001$ ) higher in $D D$ homozygotes than in the II reference group. Thus, in untreated hypertensive patients, in case-control as well as association studies, the $D$ allele behaved as a marker for left ventricular hypertrophy. The findings of this quantitative overview (Kuznetsova et al., 2000) support the hypothesis that the enhanced angiotensin-converting enzyme activity associated with the $D$ allele may promote left ventricular hypertrophy if a pathophysiological process causing this disorder, remains unopposed by treatment.

\subsubsection{Diseases of the large arteries}

In a landmark study, Cambien et al. (1992) observed an increased prevalence of the angiotensin-converting enzyme $D D$ genotype in 610 Caucasian patients with a history of myocardial infarction. Subsequent studies found that the $D$ allele was also associated with a higher risk of coronary heart disease (Nakai et al., 1994; Beohar et al., 1995), stroke (Markus et al., 1995; Kario et al., 1996), other atherosclerotic manifestations (Ohishi et al., 1993), or having a history of coronary heart disease (Tiret et al., 1993; Badenhop et al., 1995).
One quantitative overview (Staessen et al., 1997b) demonstrated a strong association between atherosclerotic cardiovascular complications and the $D / I$ polymorphism of the angiotensin-converting enzyme gene (Fig. 1). In $D D$ compared with II homozygotes, the excess risk of having a history of coronary heart disease amounted to $176 \%$. The excess risk for myocardial infarction was $45 \%$. The risk associated with the $D D$ genotype was $32 \%$ for coronary heart disease including myocardial infarction. The association between the $D D$ genotype and coronary heart disease was stronger in six Asian studies than in 31 Caucasian reports. In Asians the $D D$ vs. II odds ratio was $2.73(95 \%$ CI 2.03-3.67), whereas in Caucasians it was only 1.29 (95\% CI 1.16-1.44). The excess risk of stroke in $D D$ vs. II homozygotes was 94\%. For various other atherosclerotic manifestations, such as restenosis after angioplasty or bypass surgery, renovascular disease, or the presence of atheroslcerotic plaques or intima-media thickening at level of the carotid or femoral arteries, the excess risk in $D D$ homozygotes averaged $133 \%$.

\section{ATHEROSCLEROTIC COMPLICATIONS}

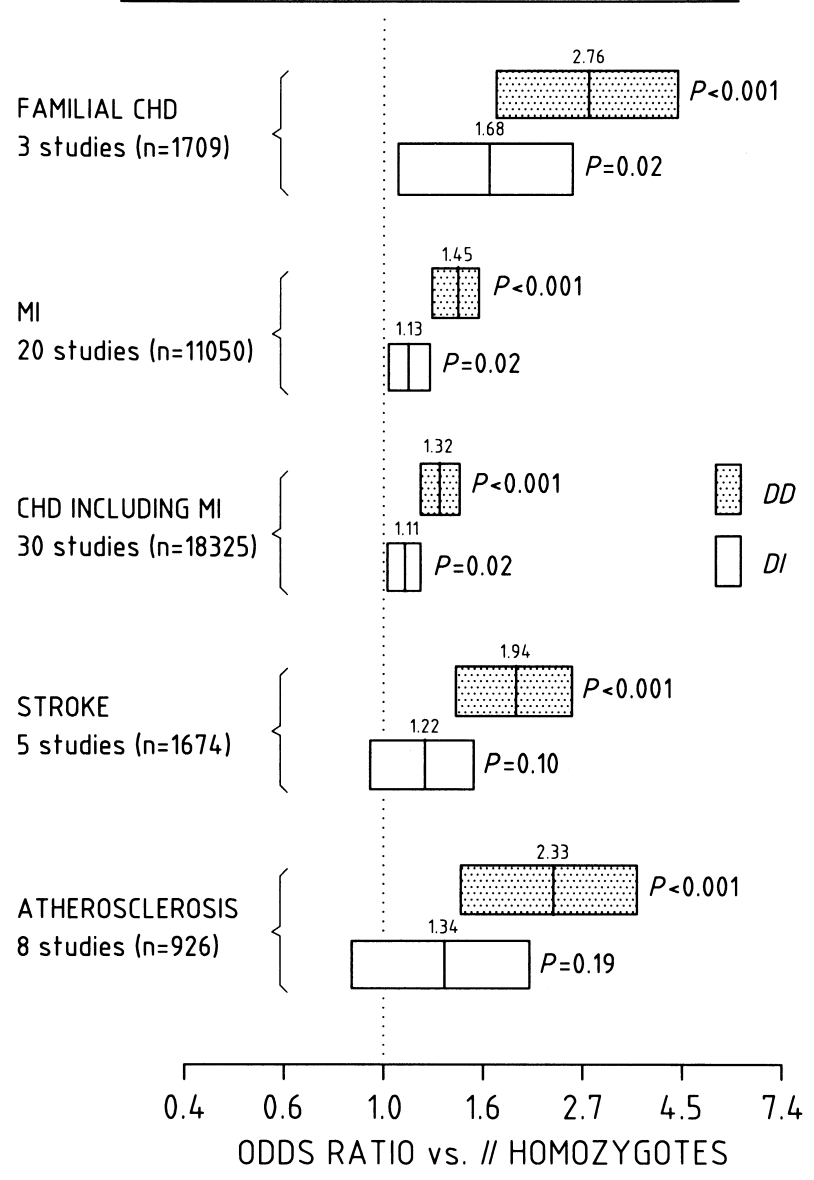

Fig. 1. Association between atherosclerotic complications and the $D$ allele of the angiotensin-converting enzyme gene. $D D$ homozygotes and the $D I$ heterozygotes were separately contrasted with $I I$ homozygotes. Odds ratios and the corresponding $P$ values are given. $\mathrm{CHD}$, coronary heart disease. MI, myocardial infarction. 
Three other meta-analyses (Samani et al., 1996; Agerholm-Larsen et al., 2000; Keavney et al., 2000) of published studies also investigated the association between the $D / I$ polymorphism and coronary heart disease. The first meta-analysis (Samani et al., 1996) included 15 studies (available by September 1995) with nearly 3400 myocardial infarction cases. The odds ratio for myocardial infarction associated with the $D D$ genotype in comparison with the $I D$ and $I I$ genotypes was 1.26 (95\% CI 1.15-1.39; $P<0.0001$ ). The second meta-analysis (Agerholm-Larsen et al., 2000) assessed the influence of $D / I$ polymorphism on the risk of myocardial infarction and ischemic heart disease only in Caucasians and differentiated the results in small studies from those in large groups. In $D D$ compared with $I D$ and $I I$ subjects the overall excess risk was $21 \%$ (95\% CI $11-32 \% ; P<0.001)$. However, the excess risk was only shown in small studies $(47 \%)$ but not in large studies.

The third meta-analysis was recently published alongside with a large UK study on the association between the $D / I$ polymorphism and myocardial infarction (Keavney et al., 2000). The analysis also provided combined risk ratios of carrying the $D D$ genotype in small (each with fewer 200 myocardial infarction cases) and large (each with 200 to about 1000 cases) studies separately. The combined risk ratio of carrying the $D D$ genotype for cases vs. controls in 35 small studies was 1.57 (99\% CI 1.38 1.78), whereas the overall results of 14 larger studies yielded a risk ratio of 0.99 (99\% CI 0.90-1.08). In the large UK study (Keavney et al., 2000), the $D D$ genotype was found in 1359 (29.4\%) of 4629 myocardial infarction cases and in $1637(27.6 \%)$ of 5934 controls. The risk ratio of carrying the $D D$ genotype in myocardial infarction cases compared with controls was 1.10 (95\% CI 1.00 1.21). Similar results were observed in the low-risk subgroup and in all other strata considered in this report.

\subsubsection{Microvascular diseases}

The associations between various microvascular disorders and the $D / I$ polymorphism have also been assessed (Fujisawa et al., 1995; Tarnow et al., 1995; Harden et al., 1995; Marre et al., 1994; Doria et al., 1994; Nomura et al., 1994; Schmidt et al., 1995). In two studies (Fujisawa et al., 1995; Tarnow et al., 1995) diabetic retinopathy was not associated with the $D$ allele. In contrast, renal diseases characterized by arteriolar and capillary lesions were more frequently $(P<0.001)$ observed in $D D$ than $I I$ homozygotes (Fig. 2). The combined excess risk of 19 studies averaged 53\% (Staessen et al., 1997b). The latter observation could be ascribed to studies on diabetic nephropathy $(+56 \%)$ and to reports on nephropathy of mixed origin $(+71 \%)$. In studies on immunoglobulin (Ig) A nephropathy, the risk associated with the $D D$ genotype was not significantly raised ( $+25 \% ; P=0.24)$ (Staessen et al., 1997b).

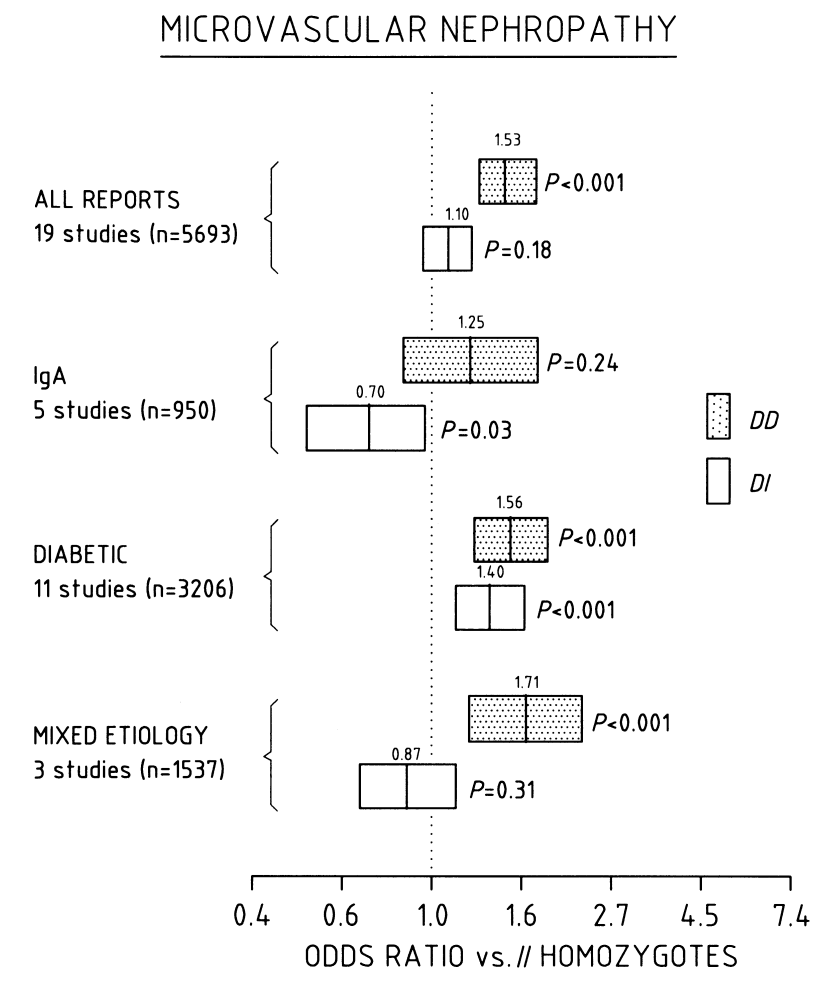

Fig. 2. Association between microvascular nephropathy and the $D$ allele of the angiotensin-converting enzyme gene. $D D$ homozygotes and the $D I$ heterozygotes were separately contrasted with II homozygotes. Odds ratios and the corresponding $P$ values are given. IgA, immunoglobulin A.

\subsection{Mechanisms of action}

Because the $D / I$ polymorphism is located within intron 16 of the angiotensin-converting enzyme gene, it is unlikely to exercise any direct effect on angiotensin-converting enzyme activity. Other alleles in linkage disequilibrium with the $D / I$ polymorphism and located within or near the angiotensin-converting enzyme gene are suspected to play a role in this regard (Tiret et al., 1992; McKenzie et al., 1995; Villard et al., 1996).

There is mounting evidence that increased angiotensinconverting enzyme gene expression and angiotensin-converting enzyme activity in the vessel wall stimulate the local rate of angiotensin II production (Müller et al., 1997; Schunkert et al., 1990; Okamura et al., 1986; Arnal et al., 1994) and in turn, influence tissue function and structure. On this basis, cardiovascular disease may develop, but probably only in the presence of disruption of systemic compensatory mechanisms due to long-term exposure to other risk factors. This probably explains why the $D D$ homozygotes have a higher risk of hypertension only in men, have excess risk of left ventricular hypertrophy only in untreated hypertensive patients, or have an increased risk of nephropathy in the presence of diabetes or other concomitant diseases. In addition, gene-gene interactions may also be important for the development of cardiovascular disorders, which usually have a multi-factorial 
etiology. One study showed synergistic effects of the angiotensin-converting enzyme $D / I$ and $\alpha$-adducin Gly460Trp polymorphism on the blood pressure response to sodium loading (Barlassina et al., 2000). In Gly / Gly homozygotes the increase in blood pressure was similar across the angiotensin-converting enzyme $D / I$ genotypes, whereas in carriers of Trp allele it was positively and linearly associated with the angiotensin-converting enzyme $D$ allele. Moreover, several studies observed a synergistic effect of the angiotensin-converting enzyme $D / I$ and angiotensin II type 1 receptor $A 1166 C$ polymorphism on the risk of coronary heart disease (Tiret et al., 1994; Álvarez et al., 1998; Fatini et al., 2000).

\section{M235T angiotensinogen gene polymorphism}

In humans, the angiotensinogen gene is located on chromosome 1q42-43 and comprises five exons and four introns spanning $12 \mathrm{~kb}$ (Gaillard et al., 1989; Jeunemaitre et al., 1997). Of nearly 20 molecular variants (Jeunemaitre et al., 1992, 1997), one polymorphism encodes threonine instead of methionine (M235T). Several studies have investigated the relationships between cardiovascular disorders and the M235T variant of the angiotensinogen gene.

\subsection{Prevalence of the $T$ allele}

In 69 studies (published before April, 1998), the overall prevalence of the $T$ allele was $52.1 \%$ (Staessen et al., 1999). The $T T, T M$ and $M M$ genotype frequencies were $30.6 \%, 42.9 \%$ and $26.5 \%$, respectively. The prevalence of the $T$ allele was dependent on race $(P<0.001)$. It was $77.0 \%$ in blacks, $78.0 \%$ in Asians, but only $42.2 \%$ in whites.

\section{2. $T$ allele and cardiovascular disease}

\subsubsection{Hypertension}

In a study involving two genetically distinct populations in Salt Lake City and Paris, the $T$ allele was significantly more frequent in hypertensive patients than in controls (Jeunemaitre et al., 1992). The prevalence of the $T$ allele was $36 \%$ in controls, $47 \%$ in unrelated index cases, and $51 \%$ in severely hypertensive patients. Moreover, TT homozygotes had approximately $20 \%$ higher concentrations of plasma angiotensinogen.

In a meta-analysis of 32 case-control studies (Staessen et al., 1999), hypertension or having a history of hypertension (Nishiuma et al., 1995) were significantly associated with the $T$ allele (Fig. 3). Compared with $M M$

\section{HYPERTENSION}

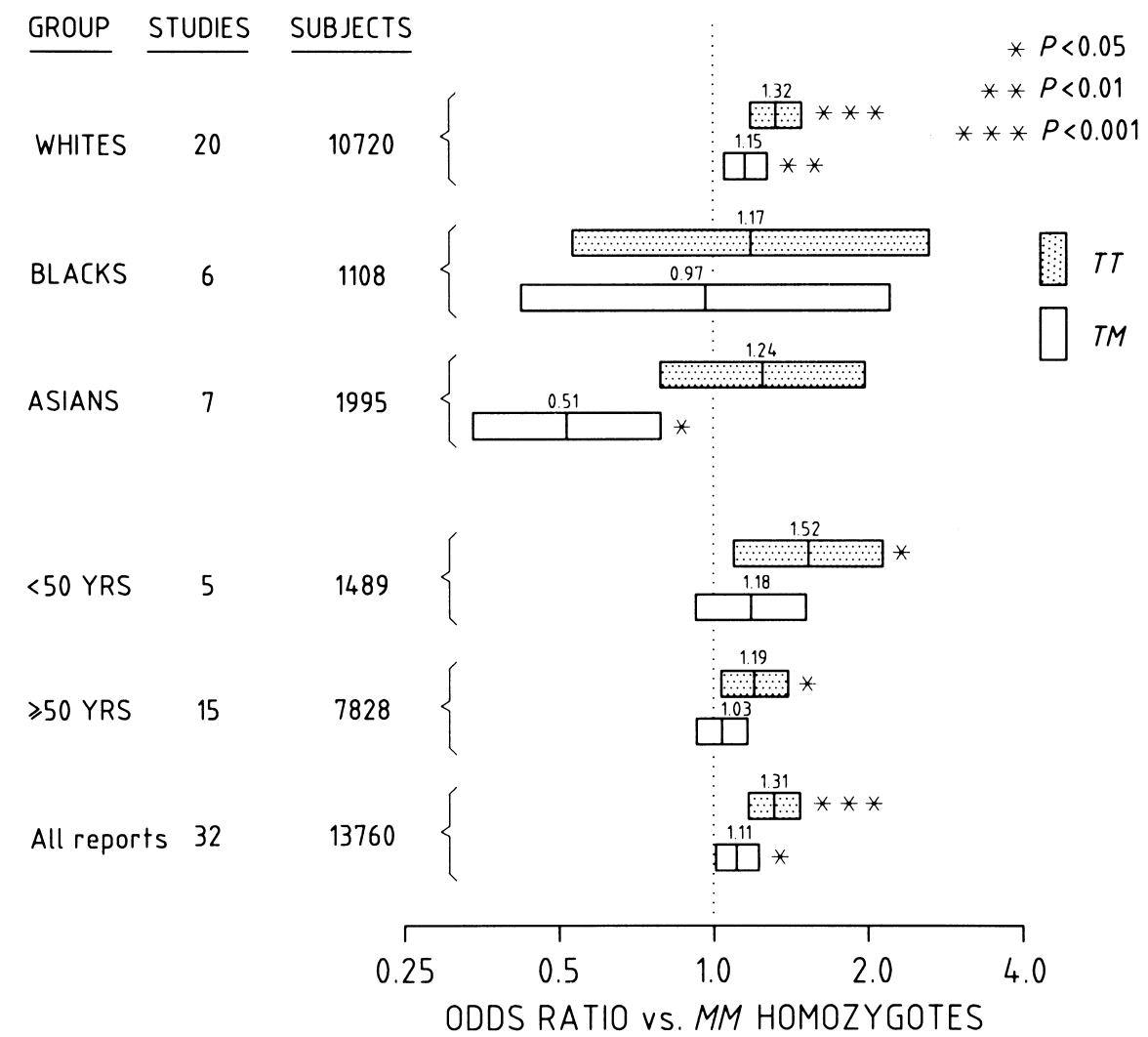

Fig. 3. Association between hypertension and the $T$ allele of the angiotensinogen gene. $T T$ homozygotes and the $T M$ heterozygotes were separately contrasted with $M M$ homozygotes. Odds ratios are given. 
homozygotes, the $T T$ and $T M$ genotypes had a $31 \%(P=$ $0.001)$ and $11 \%(P=0.03)$ excess risk. However, if different races were considered separately, the association with hypertension was only significant in Caucasians (Staessen et al., 1999), but not in Asians (Iwai et al., 1994a,b; Nishiuma et al., 1995; Chiang et al., 1997; Sato et al., 1997) and blacks (Rotimi et al., 1994, 1997; Caulfield et al., 1995; Borecki et al., 1997).

Another meta-analysis (Kunz et al., 1997) reviewed the frequency of $T$ allele with respect to hypertension in studies in Caucasians published between 1992 and 1996. In all 5493 subjects, the common odds ratio associated with the $T$ allele, compared with the $M$ variant, was 1.20 (95\% CI 1.11-1.29; $P<0.0001)$. The odds ratio increased to $1.42(95 \%$ CI $1.25-1.61)$ in subjects with a positive family history of hypertension and to 1.39 (95\% CI 1.20 1.62) in hypertensive patients recruited from referral centers. In a meta-analysis (Kato et al., 1999) restricted to seven Japanese studies with a total of 1228 hypertensive cases and 1121 controls, the odds ratio associated with $T$ allele was 1.2 (95\% CI 1.0-1.4).

\subsubsection{Cardiomyopathy}

In a Japanese study on hypertrophic cardiomyopathy (Ishanov et al., 1997), the $T$ allele frequency was higher in patients with sporadic hypertrophic cardiomyopathy than in unaffected siblings and offspring (88\% vs. 78\%; $P<$ $0.05)$. The $T$ allele frequency among the latter subjects was similar to that observed in healthy people (78\%). In another Japanese study (Yamada et al., 1997), the prevalence of the $T$ allele was not different between patients with nonfamilial hypertrophic or dilated cardiomyopathy and healthy controls. Two studies combined (Yamada et al., 1997; Ishanov et al., 1997) hypertrophic and dilated cardiomyopathy were not significantly associated with the $M 235 T$ polymorphism. In $T T$ and $T M$ subjects compared with $M M$ homozygotes, the odds ratios were 0.91 and 0.76, respectively (Staessen et al., 1999).

\subsubsection{Atheroslerotic complications}

Several studies (Katsuya et al., 1995, 1996; Ishigami et al., 1995) demonstrated a significant association between coronary heart disease and the M235T polymorphism. However, in 12 studies combined, the $T$ allele was not associated with atherosclerotic cardiovascular complications (Staessen et al., 1999). The pooled excess risk of $17 \%(P=0.08)$ in $T T$ vs. $M M$ homozygotes did not exceed the threshold of statistical significance in nine reports on coronary heart disease, including myocardial infarction. Similarly, for stroke and various other atherosclerotic manifestations, such as restenosis after angioplasty or the presence of atherosclerotic lesions (Kamitani et al., 1995; McLaughlin et al., 1995), there was no excess risk in $T T$ homozygotes compared with $M M$ homozygotes.

\subsubsection{Microvascular disease}

Diabetic retinopathy in three studies and renal diseases characterized by arteriolar or capillary lesions in 13 studies were not associated with the $T$ allele (Staessen et al., 1999). In $T T$ compared with $M M$ homozygotes, the combined odds ratios were 1.16 (95\% CI $0.76-1.77 ; P=0.49)$ for diabetic retinopathy and 1.15 (95\% CI $0.95-1.38$; $P=0.15)$ for microvascular renal diseases.

\subsection{Mechanisms of action}

Several mechanisms may explain the significant association between hypertension and the M235T polymorphism. First, the large amount of angiotensinogen in the circulation does not constitute an excess substrate for renin cleavage (Bohlender et al., 1996; Caulfield et al., 1996). Accordingly, an increase in the angiotensinogen concentration will lead to increased angiotensin I generation, even if the plasma renin concentration does not change (Bohlender et al., 1996; Caulfield et al., 1996). Second, in gene titration experiments in mice (Kim et al., 1995; Inoue et al., 1997; Smithies, 1997) or rats (Bohlender et al., 1996), the plasma angiotensinogen concentration rose progressively, although not linearly, from zero in the zero copy animals to $145 \%$ of normal in four-copy animals (Bohlender et al., 1996; Inoue et al., 1997; Smithies, 1997). Increased angiotensinogen gene expression also causes hypertension (Bohlender et al., 1996; Kim et al., 1995; Smithies, 1997). Third, recent studies have shown that the human angiotensinogen gene promoter element 1 , located in the $5^{\prime}$ upstream core promoter region (position -25 to -1 ), plays an important role in the expression of angiotensin mRNA by binding with the transcription factor (Fukamizu et al., 1989; Tamura et al., 1994; Yanai et al., 1996). Mutations in this area, such as the A-20C (Ishigami et al., 1997) and G-6A (Inoue et al., 1997) base-pair substitutions, are in almost complete linkage disequilibrium with the M235T variant in exon 2 of the angiotensinogen gene (Jeunemaitre et al., 1997). Recent human studies showed a significant correlation of the $G-6 A$ (Jeunemaitre et al., 1997) and A-20C (Ishigami et al., 1997) variants with the plasma angiotensinogen concentration (Ishigami et al., 1997) and essential hypertension (Jeunemaitre et al., 1997; Ishigami et al., 1997).

\section{A1166C polymorphism of the angiotensin II type 1 receptor gene}

An $A \rightarrow C$ transversion at nucleotide position 1166 was located in the $3^{\prime}$ untranslated region of the angiotensin II type 1 receptor gene (Table 1) (Bonnardeaux et al., 1994). Several studies have shown that it was associated with hypertension (Bonnardeaux et al., 1994), left ventricular hypertrophy (Takami et al., 1998), coronary heart disease, 
myocardial infarction (Tiret et al., 1994), and progression of diabetic nephropathy (Tomino et al., 1999).

\subsection{Prevalence of the $C$ allele}

The overall frequency of the $C$ allele in 13 studies (published before November, 1996) with 4332 subjects was $25.7 \%$ (Staessen et al., 1997a). The prevalence of the $C$ allele (28.8\% vs. $9.2 \%$ ), $C C$ homozygosity (7.7\% vs. $1.1 \%)$ and $C A$ heterozygosity $(42.1 \%$ vs. $16.2 \%)$ was significantly higher in Caucasians than Asians $(P<0.001)$.

\subsection{The $C$ allele and cardiovascular disease}

\subsubsection{Hypertension}

In a case-control study on hypertension in white people, the frequency of the $C$ allele was significantly higher in 206 hypertensive patients than in 298 normotensive subjects $(36 \%$ vs. $28 \% ; P<0.01)$ (Bonnardeaux et al., 1994). The finding was confirmed by two (Wang et al., 1997; Miyamoto et al., 1996) of three (Wang et al., 1997; Miyamoto et al., 1996; Takami et al., 1998) subsequent case-control studies. The frequencies of the $C$ allele and the $C C$ genotype in 108 Caucasian hypertensive patients with a family history of hypertension were significantly higher than in 84 normotensive controls (Wang et al., 1997). In $C C$ homozygotes compared with $A C$ and $A A$ subjects combined, the odds ratio for hypertension was 7.3 (95\% CI 1.9-31.9). The prevalence of the $C$ allele was higher in 90 Japanese hypertensive patients than in 89 normotensive controls $(11.7 \%$ vs. $3.9 \% ; \quad P<0.001)$ (Miyamoto et al., 1996). No significant association between hypertension and the $C$ allele was observed in another Japanese study that included 321 hypertensive cases and 215 control subjects (Takami et al., 1998). The frequency of the $C$ allele was similar in both groups. In addition, both systolic and diastolic blood pressures were not significantly different across the $A 1166 C$ genotypes (Takami et al., 1998).

Three association studies on the $A 1166 C$ polymorphism considered blood pressure as a continuous trait (Hingorani et al., 1995; Castellano et al., 1996; Zhang et al., 2000). The results of these studies were not consistent. In an Italian study of 125 previously untreated hypertensive patients (Hingorani et al., 1995), both systolic and diastolic blood pressure were positively and linearly associated with the number of $C$ alleles after accounting for sex, age, body mass index, alcohol intake, and the M235T polymorphism of the angiotensinogen gene. Among 212 subjects randomly selected from a general population in northern Italy (Castellano et al., 1996), clinic systolic and diastolic blood pressures were on average $11.3 \mathrm{~mm} \mathrm{Hg}$ $(P=0.005)$ and $4.2 \mathrm{~mm} \mathrm{Hg}(P=0.01)$ lower in $C C$ homozygotes than $A C$ heterozygotes and $A A$ homozygotes. Ambulatory blood pressure was similar across the A1166C genotypes. In 548 German participants in the
MONICA (Monitoring Trends and Determinants in Cardiovascular Disease) study (Zhang et al., 2000), the prevalence of $C C$ homozygosity was only 5\% and both blood pressure levels and the prevalence of hypertension were not related to the $A 1166 C$ polymorphism.

\subsubsection{Diseases of myocardium}

Several studies examined the association between the A1166C polymorphism and left ventricular hypertrophy (Castellano et al., 1996; Hamon et al., 1997; Takami et al., 1998), or hypertrophic (Osterop et al., 1998) or dilated cardiomyopathy (Tiret et al., 2000). In 61 Japanese normotensive subjects-but not in 110 hypertensive patients - the $C$ allele was associated with a greater left ventricular wall thickness, intraventricular septum, and left ventricular mass index $(P<0.05)$ (Takami et al., 1998). However, these results were not confirmed by two studies in Caucasians (Castellano et al., 1996; Hamon et al., 1997).

In a study of 104 genetically independent subjects with hypertrophic cardiomyopathy, the $C$ allele was associated with a higher left ventricular mass (Osterop et al., 1998). The left ventricular mass index was $190 \pm 8$ (S.E.) $\mathrm{g} / \mathrm{m}^{2}$ in subjects carrying the $C$ allele and $168 \pm 7 \mathrm{~g} / \mathrm{m}^{2}$ in $A A$ homozygotes $(P=0.01)$. Using the case-control approach, the $C$ allele was not significantly associated with the risk or the severity of the idiopathic dilated cardiomyopathy (Tiret et al., 2000).

\subsubsection{Atherosclerotic complications}

At least three studies observed synergistic effects of the angiotensin-converting enzyme $D / I$ and the angiotensin II type 1 receptor $A 1166 C$ polymorphisms on the risk of myocardial infarction (Tiret et al., 1994) or coronary heart disease (Álvarez et al., 1998; Fatini et al., 2000). In a case-control study of 613 myocardial infarction cases and 723 age-matched population controls (Tiret et al., 1994), the odds ratio associated with the angiotensin-converting enzyme $D D$ genotype was 1.05 (95\% CI $0.75-1.49)$ in subjects without the $C$ allele of the angiotensin II type 1 receptor gene, 1.52 (95\% CI 1.06-2.18) in $A C$ heterozygotes and 3.95 (95\% CI 1.26-12.4) in CC homozygotes (test for trend $P<0.02$ ). Another study included 181 patients younger than 50 years who had a history of myocardial infarction or unstable angina and 240 controls from the same homogeneous Caucasian population in northern Spain (Álvarez et al., 1998). The odds ratio for coronary heart disease associated with the $D D$ genotype was $5.32(95 \%$ CI $1.45-19.51 ; \mathrm{P}=0.02)$ in $C C$ homozygotes and only $1.01(95 \%$ CI $0.33-5.39 ; P=0.31)$ in carriers of $A$ allele. More recently, an Italian study recruited 205 patients with a history of myocardial infarction or angina pectoris and with angiographically documented coronary artery stenosis $(>75 \%)$ and 209 controls (Fatini et al., 2000). After accounting for hypertension, body mass index, diabetes, dyslipidemia and smoking, the odds ratios for coronary heart disease associated with the angiotensin- 
converting enzyme $D D$, the angiotensin II type 1 receptor $C C$, and both genotypes were $1.81(P=0.01), 2.61(P=$ $0.01)$, and $4.02(P<0.0001)$, respectively.

Synergistic effects of the angiotensin-converting enzyme $D$ and the angiotensin II type 1 receptor $C$ allele were also observed for malignant ventricular arrhythmias in patients with coronary heart disease and for a history of malignant ventricular arrhythmias treated by an implantable cardioverter defibrillator (Anvari et al., 1999). The odds ratio for malignant ventricular arrhythmias was 2.4 per number of $D / C$ alleles (95\% CI 1.41-3.94, $P<0.001)$. The angiotensin II type 1 receptor $C$ allele was also found to be associated with coronary atheroma (Rice et al., 1999), the development of coronary artery stenosis (Nakauchi et al., 1996), or the number of lacunae in the brain (Takami et al., 2000).

Benetos et al. in a French population found that the $C$ allele was associated with higher pulse wave velocity in hypertensive patients (Benetos et al., 1995, 1996b), but not in normotensive subjects (Benetos et al., 1996b). The $C$ allele was also associated with the magnitude of change in pulse wave velocity produced by antihypertensive drug treatment (Benetos et al., 1996a). An angiotensin-converting enzyme inhibitor (perindopril) reduced pulse wave velocity more in carriers of the $C$ allele than in $A A$ homozygotes, whereas a calcium-channel blocker (nitrendipine) decreased pulse wave velocity only in $A A$ homozygotes. However, also in a French population, Girerd et al. (1998) failed to demonstrate a significant association between the wall thickness of the radial and carotid arteries and the $A 1166 C$ polymorphism.

\subsubsection{Microvascular complications}

Studies on nephropathy were not consistent (Hunley et al., 1996; Tarnow et al., 1996; Marre et al., 1997; Yudkin et al., 1997; Tomino et al., 1999). Only a Japanese study found that in a sample of 114 non-insulin-dependent diabetic female patients with overt albuminuria, the $C$ allele was associated with a higher risk of renal insufficiency (Tomino et al., 1999). Other studies did not show any evidence for the association between the $A 1166 C$ polymorphism and susceptibility or progression of renal diseases characterized by arteriolar or capillary lesions in subjects with diabetes (Tarnow et al., 1996; Marre et al., 1997), microalbuminuria (Yudkin et al., 1997), or IgA (immunoglobulin A) nephropathy (Hunley et al., 1996).

\subsection{Mechanisms of action}

The associations between cardiovascular disease and the A1166C polymorphism in the angiotensin II type 1 receptor gene are thought to be due to linkage disequilibrium with other polymorphisms in the angiotensin II type 1 receptor gene or in other genes. Indeed, several studies observed an epistatic interaction between the angiotensinconverting enzyme $D / I$ and the angiotensin II type 1 receptor A1166C polymorphism (Tiret et al., 1994; Álvarez et al., 1998; Fatini et al., 2000).

Two recent studies have revealed an association between the $A 1166 C$ polymorphism and the sensitivity of the angiotensin II type 1 receptor in human vessels (Amant et al., 1997; van Geel et al., 2000). In 140 patients with normal coronary arteries, 13 CC homozygotes had significantly greater vasoconstriction in distal coronary vessels in response to methylergonovine maleate injection $(P<$ 0.009) (Amant et al., 1997). In line with this finding, another study demonstrated that the $C$ allele was associated with an increased vasoreactivity to angiotensin II in human arteries (van Geel et al., 2000). The enhanced vasoconstriction associated with the $A 1166 C$ polymorphism may partially account for the higher blood pressure in $C$ allele bearers (Bonnardeaux et al., 1994). The same mechanism may directly contribute to the excess risk of myocardial infarction and angina pectoris in carriers of $C$ allele.

\section{Other gene polymorphisms in the renin-angiotensin system}

5.1. $4656(C T)_{2 / 3}$ polymorphism of the angiotensin-converting enzyme gene

The $4656(C T)_{2 / 3}$ polymorphism of the angiotensinconverting enzyme gene depends on a repetition of two or three $C T$ nucleotides (Table 1) (Villard et al., 1996). In parents of 95 healthy nuclear families, after adjustment for the angiotensin-converting enzyme $D / I$ variant, the $4656(C T)_{2 / 3}$ polymorphism was still associated with serum angiotensin-converting enzyme levels $(P=0.04)$. This polymorphism has not yet been found to be associated with any cardiovascular disease.

\subsection{Other polymorphisms of the angiotensinogen gene}

\subsubsection{T174M angiotensinogen gene polymorphism}

The $T 174 M$ polymorphism is in complete linkage disequilibrium with the $M 235 T$ variant $(P<0.0001)$ (Jeunemaitre et al., 1992); $174 M$ allele is present in a subset of chromosomes carrying the $235 T$ allele. The overall frequency of the $M$ allele of the $T 174 M$ variant in 12 studies with 4952 subjects was $11.0 \%$ (Staessen et al., 1997a). The $M M$ homozygotes made up $1.2 \%$ of all subjects examined. Race was a major determinant of the $M$ allele frequencies, which was similar among Caucasians $(12.9 \%)$ and Asians $(10.9 \%)$, but which was as low as $6.0 \%$ in blacks $(P<0.001$ for difference with the other races).

The $T 174 M$ polymorphism was also associated with hypertension (Jeunemaitre et al., 1992) and examined for association with other cardiovascular disorders (Marre et al., 1997). However, this polymorphism did not provide 
more informative evidence over and above the M235T variant.

5.2.2. A-20C, C-18T and G-6A polymorphisms in the promoter region of the angiotensinogen gene

A cis-acting DNA element located between the TATA box and the transcription initiation site is critical in the response to the regulatory sequence in angiotensinogen gene (Yanai et al., 1996). Sequence difference in this angiotensinogen core promotor element 1 (at -25 to -1 base region upstream from transcriptional initiation site) alters the binding affinity of a ubiquitous transcriptional factor, angiotensinogen core promotor element binding factor 1 . When three haplotypes (at -20 to -18 ) in the angiotensinogen core promotor element 1 were compared, CTC and ATC showed 2.5 times higher transcriptional activity than $A T T$. Furthermore, recent transfection data show that a human angiotensinogen gene promoter containing the $-20 \mathrm{C}$ mutation transcribes a reporter gene at a greater level than the $-20 A$ (Zhao et al., 1999). Therefore, the $A-20 C$ polymorphism may also affect transcription activity of angiotensinogen mRNA in humans and hence alter the plasma angiotensinogen level.

The $A-20 C$ and $M 235 T$ variants are in close linkage disequilibrium (Sato et al., 1997). The frequency of the $-20 \mathrm{C}$ allele was $27 \%$ in Japanese (Ishigami et al., 1997) and $19 \%$ and $14 \%$ in Caucasian hypertensive patients and normotensive controls, respectively (Jeunemaitre et al., 1992). In Japanese, the $-20 C$ allele was reported to be associated with a higher level of plasma angiotensinogen (Ishigami et al., 1997, 1999) and a higher risk of hypertension (Ishigami et al., 1997). However, the findings were not confirmed by other investigators (Sato et al., 1997; Jeunemaitre et al., 1992, 1997).

The frequency of the $-18 T$ allele was $1 \%$ and $4 \%$ in Japanese hypertensive patients and normotensive controls (Sato et al., 1997), respectively, and 13\% in Caucasian people (Jeunemaitre et al., 1992). The $C$ - $18 T$ polymorphism was associated with hypertension in Japanese (Sato et al., 1997), but not in Caucasians (Jeunemaitre et al., 1992). In the Japanese study, the odds ratio for hypertension in $C C$ homozygotes compared with carriers of the $T$ allele was 4.2 (95\% CI $1.4-12.8 ; P<0.005)$.

The $-6 A$ allele of the $G-6 A$ polymorphism of the angiotensinogen gene was associated with a greater in-vitro angiotensinogen gene transcription and expression (Inoue et al., 1997). This apparently functional polymorphism is in nearly complete disequlibrium with the M235T locus. The $-6 A$ allele was associated with higher blood pressure in a cross-sectional study of 274 Japanese outpatients (Ishigami et al., 1999) and also associated with a higher risk of hypertension in a case-control study involving both Caucasian and Japanese subjects (Jeunemaitre et al., 1997). Among 1509 participants in the Trials of Hypertension Prevention study, $A A$ homozygotes in the usual care group had a higher 3-year incidence rate of hypertension (44.6\%) than $G G$ homozygotes $(31.5 \%)$ (Hunt et al., 1998). The relative risk was 1.4 (95\% CI $0.87-2.34$; test for trend across all three genotypes $P=0.10$ ). After dietary sodium restriction, the incidence of hypertension was significantly lower in $A A$ homozygotes (relative risk vs. usual care $0.57,95 \%$ CI $0.34-0.98$ ), but not in $G G$ homozygotes (relative risk $1.2,95 \% \mathrm{CI} 0.79-1.81$; test for trend $P=$ 0.02). For the effects of weight loss on hypertension incidence, the trends across genotypes were similar to those for sodium restriction. Therefore, the angiotensinogen $G-6 A$ polymorphism may affect blood pressure response to sodium or weight reduction and the development of hypertension. However, the NHLBI (National Heart Lung Blood Institute) Family Blood Pressure Program showed that the $G-6 A$ polymorphism had minimal to no effect on the inter-individual variation of blood pressure in Caucasians, African Americans and Asians (Province et al., 2000).

\subsection{T-810A polymorphism of the angiotensin II type 1 receptor gene}

Among many polymorphisms identified in the angiotensin II type 1 receptor gene, the $T-810 \mathrm{~A}$ locus may be associated with myocardial infarction (Poirier et al., 1998). The $-810 \mathrm{~A}$ allele frequency was significantly lower in 631 Caucasian myocardial infarction cases than in 725 controls $(15 \%$ vs. $18 \% ; P<0.05)$. The odds ratio associated with the $-810 \mathrm{~A}$ allele for myocardial infarction was 0.80 (95\% CI 0.65-0.97). In the same study, this polymorphism was not associated with blood pressure.

\section{Conclusions and discussions of future research}

Genetic studies of the components of the renin-angiotensin system produced evidence that several genetic polymorphisms, acting alone or in concert, may behave as markers of various cardiovascular disorders. Further studies on the pathogenetic mechanisms linking these genetic variants and cardiovascular disease are of paramount importance. A large number of patients with hypertension, myocardial infarction, or congestive heart failure are currently on treatment with angiotensin-converting enzyme inhibitors or angiotensin II type 1 receptor antagonists. The efficacy of these drugs across different genotypes should also be investigated in terms of blood pressure reduction as well as prevention of mortality and morbidity.

Several lessons can be drawn from the present review in terms of the preferable directions of future research projects. First, more attention should be paid to the standardization of the phenotype, especially for continuous and highly variable traits, such as blood pressure. Second, more energy should be invested in the definition of intermediary phenotypes, which can be easily measured on a large scale and which may link genes of interest to disease 
outcomes. Paradigms, such as for instance the role of the angiotensin-converting enzyme and angiotensinogen in the pathogenesis of atherosclerosis or hypertension, respectively, should also be developed for other genes and other diseases. Third, polygenic disorders arise through interaction between genetic predisposition, lifestyle and environmental factors. Thus, future studies should not only have sufficient sample size to detect small genetic effects, but should also consider gene-gene interaction (Frankel and Schork, 1996) and interaction between genetic background and other environmental factors. Fourth, the genetic factors involved in chronic illnesses are likely to differ across races, because of the varying frequencies of alleles and genotypes. Such important information may be drawn from the investigation and comparison of racially homogeneous populations, using strictly standardized epidemiological methods. Along these lines, a population-based study of nuclear families is currently being conducted in Gaoping City, near Beijing, in the People's Republic of China in the framework of the collaboration between the Chinese and Flemish governments. The epidemiological and genetic techniques used in this Chinese study are the same as those employed in other population studies in Belgium (Staessen et al., 2000) and Europe. It is to be expected that comparative genetic studies may offer a new and informative approach to polygenic diseases, such as hypertension and atherosclerosis.

\section{Acknowledgements}

Collaborative genetic research in Belgium and China was made possible by research grants G.0174.97 and G.0291.98 from the Fonds voor Wetenschappelijk Onderzoek Vlaanderen (Brussels, Belgium) and by a special research grant (Onderzoekstoelage OT/99/28) from the Katholieke Universiteit Leuven, and through collaboration between the Chinese and Flemish Governments (BIL 98/03). The authors also gratefully acknowledge the critical comments from Professor W. H. Birkenhäger (Erasmus University, Rotterdam, The Netherlands) and Dr. L. Balkestein (University of Maastricht, Maastricht, The Netherlands).

\section{References}

ACE Inhibitor Myocardial Infarction Collaborative Group, 1998. Indications for ACE inhibitors in the early treatment of acute myocardial infarction. Systematic overview of individual data from 100,000 patients in randomized trials. Circulation 97, 2202-2212.

Agerholm-Larsen, B., Nordestgaard, B.G., Tybjaerg, H.A., 2000. ACE gene polymorphism in cardiovascular disease: meta-analysis of small and large studies in Whites. Arterioscler. Thromb. Vasc. Biol. 20, 484-492.

Álvarez, R., Reguero, J.R., Batalla, A., Iglesias-Cubero, G., Cortina, A., Álvarez, V., Coto, E., 1998. Angiotensin-converting enzyme and angiotensin II receptor 1 polymorphisms: association with early coronary disease. Cardiovasc. Res. 40, 375-379.

Amant, C., Hamon, M., Bauters, C., Richard, F., Helbecque, N., McFad- den, E.P., Escudero, X., Lablanche, J.M., Amouyel, P., Bertrand, M.E., 1997. The angiotensin II type 1 receptor gene polymorphism is associated with coronary artery vasoconstriction. J. Am. Coll. Cardiol. $29,486-490$

Anvari, A., Türel, Z., Schmidt, A., Yilmaz, N., Mayer, G., Huber, K., Schuster, E., Gottsauner-Wolf, M., 1999. Angiotensin-converting enzyme and angiotensin II receptor 1 polymorphism in coronary disease and malignant ventricular arrhythmias. Cardiovasc. Res. 43, 879-883.

Arnal, J.F., Battle, T., Rasetti, C., Challah, M., Costerousse, O., Vicaut, E., Michel, J.B., Alhenc-Gelas, F., 1994. ACE in three tunicae of rat aorta: expression in smooth muscle and effect of renovascular hypertension. Am. J. Physiol. 267, H1777-H1784.

Azizi, M., Guyene, T.T., Chatellier, G., Wargon, M., Ménard, J., 1997. Additive effects of losartan and enalapril on blood pressure and plasma active renin. Hypertension 29, 634-640.

Badenhop, R.F., Wang, X.L., Wilcken, D.E.L., 1995. Angiotensin-converting enzyme genotype in children and coronary events in their grandparents. Circulation 91, 1655-1658.

Barlassina, C., Schork, N.J., Manuta, P., Citterio, L., Sciarrone, M.T., Lanella, G., Bianchi, G., Cusi, D., 2000. Synergistic effect of $\alpha$-adducin and ACE genes causes blood pressure changes with body sodium and volume expansion. Kidney Int. 57, 1083-1090.

Benetos, A., Topouchian, J., Ricard, S., Gautier, S., Bonnardeaux, A., Asmar, R., Poirier, O., Safar, M., Soubrier, F., Cambien, F., 1995. Influence of angiotensin II type 1 receptor polymorphism on aortic stiffness in never-treated hypertensive patients. Hypertension 26, 4447.

Benetos, A., Cambien, F., Gautier, S., Ricard, S., Safar, M., Laurent, S., Lacolley, P., Poirier, O., Topouchian, J., Asmar, R., 1996a. Influence of the angiotensin II type 1 receptor gene polymorphism on the effects of perindopril and nitrendipine on arterial stiffness in hypertensive individuals. Hypertension 28, 1081-1084.

Benetos, A., Gautier, S., Ricard, S., Tpouchian, J., Asmar, R., Poirier, O., Larosa, E., Guize, L., Safar, M., Soubrier, F., Cambien, F., 1996b. Influence of angiotensin converting enzyme and angiotensin II type 1 receptor gene polymorphisms on aortic stiffness in normotensive and hypertensive patients. Circulation 94, 698-703.

Beohar, N., Damaraju, S., Prather, A., Yu, Q.T., Raizner, A.E., Kleiman, N.S., Marian, R.R., 1995. Angiotensin converting enzyme genotype DD is a risk factor for coronary heart disease. J. Invest. Med. 43, 275-280.

Bohlender, J., Ménard, J., Wagner, J., Luft, F.C., Ganten, D., 1996. Human renin-dependent hypertension in rats transgenic for human angiotensinogen. Hypertension 27, 535-540.

Bonnardeaux, A., Davies, E., Jeunemaitre, X., Féry, I., Charru, A., Clauser, E., Tiret, L., Cambien, F., Corvol, P., Soubrier, F., 1994. Angiotensin II type-1 receptor gene polymorphisms in human essential hypertension. Hypertension 24, 63-69.

Borecki, I.B., Province, M.A., Ludwig, E.H., Ellison, R.C., Folsom, A.R., Heiss, G., Lalouel, J.M., Higgins, M., Rao, D.C., 1997. Associations of candidate loci angiotensinogen and angiotensin-converting enzyme with severe hypertension: the NHLBI Family Heart Study. Ann. Epidemiol. 7, 13-21.

Cambien, F., Poirier, O., Lecerf, L., Evans, A., Cambou, J.P., Arveiler, D., Luc, G., Bard, J.M., Bara, L., Ricard, S., Tiret, L., Amouyel, P., Alhenc-Gelas, F., Soubrier, F., 1992. Deletion polymorphism in the gene for angiotensin-converting enzyme is a potent risk factor for myocardial infarction. Nature 359, 641-644.

Campbell, D.J., 1987. Tissue renin-angiotensin system: sites of angiotensin formation. J. Cardiovasc. Pharmacol. 10 (Suppl. 7), S1-S8.

Castellano, M., Muiesan, M.L., Beschi, M., Rizzoni, D., Cinelli, A., Salvetti, M., Pasini, G., Porteri, E., Bettoni, G., Zulli, R., Agabiti Rosei, E., 1996. Angiotensin II type 1 receptor A/C ${ }^{1166}$ polymorphism. Relationships with blood pressure and cardiovascular structure. Hypertension 28, 1076-1080.

Caulfield, M., Lavender, P., Newell-Price, J., Farrall, M., Kamdar, S., Daniel, H., Lawson, M., De Freita, P., Fogarty, P., Clark, A.J.L., 
1995. Linkage of the angiotensinogen gene locus to human essential hypertension in African Caribbeans. J. Clin. Invest. 96, 687-692.

Caulfield, M., Lavender, P., Newell-Price, J., Kamdar, S., Farrall, M., Clark, A.J.L., 1996. Angiotensinogen in human essential hypertension. Hypertension 28, 1123-1125.

Chiang, F.T., Hsu, K.L., Tseng, C.D., Hsiao, W.H., Lo, H.M., Chern, T.H., Tseng, Y.Z., 1997. Molecular variant M235T of the angiotensinogen gene is associated with essential hypertension in Taiwanese. J. Hypertens. 15, 607-611.

Danser, A.H.J., Schalekamp, M.A.D.H., Bax, W.A., Maassen van den Brink, A., Saxena, P.R., Riegger, G.A.J., Schunkert, H., 1995. Angiotensin-converting enzyme in the human heart. Effect of the deletion/insertion polymorphism. Circulation 92, 1387-1388.

Doria, A., Warram, J.H., Krowelski, A.S., 1994. Genetic predisposition to diabetic nephropathy: evidence for a role of the angiotensin I converting enzyme gene. Diabetes 43, 690-695.

Dzau, V.J., 1993. Tissue renin-angiotensin system in myocardial hypertrophy and failure. Arch. Intern. Med. 153, 937-942.

Fatini, C., Abbate, R., Pepe, G., Battaglini, B., Gensini, F., Ruggiano, G., Gensini, G.F., Guazzelli, R., 2000. Searching for a better assessment of the individual coronary risk profile. The role of angiotensin-converting enzyme, angiotensin II type 1 receptor and angiotensinogen polymorphisms. Eur. Heart J. 21, 633-638.

Frankel, W.N., Schork, N.J., 1996. Who's afraid of epistasis? Nat. Genet. 14, 371-373.

Fujisawa, T., Ikegami, H., Shen, G.Q., Yamato, E., Takekawa, K., Nakagawa, Y., Hamada, Y., Ueda, H., Rakugi, H., Higaki, J., Ohishi, M., Fujii, K., Fukuda, M., Ogihara, T., 1995. Angiotensin-I-converting enzyme gene polymorphism is associated with myocardial infarction, but not with retinopathy or nephropathy, in NIDDM. Diabetes Care 18, 983-985.

Fukamizu, A., Takahashi, S., Seo, M.S., Tada, M., Tanimoto, K., Uehara, S., Murakami, K., 1989. Structure and expression of the human angiotensinogen gene. Identification of a unique and highly active promoter. J. Biol. Chem. 265, 7576-7582.

Gaillard, I., Clauser, E., Corvol, P., 1989. Structure of the human angiotensinogen gene. DNA 8, 87-99.

Gharavi, A.G., Lipkowitz, M.S., Diamond, J.A., Jhang, J.S., Phillips, R.A., 1996. Deletion polymorphism of the angiotensin-converting enzyme gene is independently associated with left ventricular mass and geometric remodeling in systemic hypertension. Am. J. Cardiol. $77,1315-1319$

Girerd, X., Hanon, O., Mourad, J.J., Boutouyrie, P., Laurent, S., Jeunemaitre, X., 1998. Lack of association between renin-angiotensin system, gene polymorphisms, and wall thickness of the radial and carotid arteries. Hypertension 32, 579-583.

Gu, X.X., Spaepen, M., Guo, C., Fagard, R., Amery, A., Lijnen, P., Cassiman, J.J., 1994. Lack of association between the I/D polymorphism of the angiotensin-converting enzyme gene and essential hypertension in a Belgian population. J. Hum. Hypertens. 8, 683-685.

Hall, J.H., Mizelle, H.L., Woods, L.L., 1986. The renin-angiotensin system and long-term regulation of blood pressure. J. Hypertens. 4, 387-397.

Hamon, M., Amant, C., Bauters, C., Richard, J., Helbecque, N., Mc Fadden, E., Lablanche, J.M., Bertrand, B., Amouyel, P., 1997. Association of angiotensin converting enzyme and angiotensin II type 1 receptor genotypes with left ventricular function and mass in patients with angiographically normal coronary arteries. Heart 77, 502-505.

Harden, P.N., Geddes, C., Rowe, P.A., McIlroy, J.H., Boulton-Jones, M., Rodger, R.S.C., Junor, B.J.R., Briggs, J.D., Connell, J.M.C., Jardine, A.G., 1995. Polymorphisms in angiotensin-converting-enzyme gene and progression of IgA nephropathy. Lancet 345, 1540-1542.

Higaki, J., Baba, S., Katsuya, T., Sato, N., Ishikawa, K., Mannami, T., Ogata, J., Ogihara, T., 2000. Deletion allele of angiotensin-converting enzyme gene increases risk of essential hypertension in Japanese men. The Suita Study. Circulation 101, 2060-2065.

Higashimori, K., Zhao, Y., Higaki, J., Kamitani, A., Katsuya, T., Nakura,
J., Miki, T., Mikami, H., Ogihara, T., 1993. Association analysis of a polymorphism of the angiotensin converting enzyme gene with essential hypertension in the Japanese population. Biochem. Biophys. Res. Commun. 191, 399-404.

Hingorani, A.D., Jia, H., Stevens, P.A., Hopper, R., Dickerson, J.E.C., Brown, M.J., 1995. Renin-angiotensin system gene polymorphisms influence blood pressure and the response to angiotensin converting enzyme inhibition. J. Hypertens. 13, 1602-1609.

Hunley, T.E., Julian, B.A., Phillips, J.A. III, Summar, M.L., Yoshida, H., Horn, R.G., Brown, N.J., Fogo, A., Ichikawa, I., Kon, V., 1996. Angiotensin converting enzyme gene polymorphism: potential silencer motif and impact on progression in IgA nephropathy. Kidney Int. 49, 571-577.

Hunt, S.C., Cook, N.R., Oberman, A., Cutler, J.A., Hennekens, C.H., Allender, P.S., Walker, W.G., Whelton, P.K., Williams, R.R., 1998. Angiotensinogen genotype, sodium reduction, weight loss, and the prevention of hypertension. Trials of hypertension prevention, phase II. Hypertension 32, 393-401.

Inoue, I., Nakajima, T., Williams, C.S., Quackenbush, J., Puryear, R., Powers, M., Cheng, T., Ludwig, E.H., Sharma, A.M., Hata, A., Jeunemaitre, X., Lalouel, J.M., 1997. A nucleotide substitution in the promoter of human angiotensinogen is associated with essential hypertension and affects basal transcription in vitro. J. Clin. Invest. 99, 1786-1797.

Ishanov, A., Okamoto, H., Yoneya, K., Watanabe, M., Nakagawa, I., Machida, M., Onozuka, H., Mikami, T., Kawaguchi, H., Hata, A., Kondo, K., Kitabatake, A., 1997. Angiotensinogen polymorphism in Japanese patients with hypertrophic cardiomyopathy. Am. Heart J. 133, 184-189.

Ishigami, T., Umemura, S., Iwamoto, T., Tamura, K., Hibi, K., Yamaguchi, S., Nyuui, N., Kimura, K., Miyazaki, N., Ishii, M., 1995. Molecular variant of angiotensinogen gene is associated with coronary atherosclerosis. Circulation 91, 951-954.

Ishigami, T., Umemura, S., Tamura, K., Hibi, K., Nyui, N., Kihara, M., Yabana, M., Watanabe, Y., Sumida, Y., Nagahara, T., Ochiai, H., Ishii, M., 1997. Essential hypertension and 5' upsteam core promoter region of human angiotensinogen gene. Hypertension 30, 1325-1330.

Ishigami, T., Tamura, K., Fujita, T., Kobayashi, I., Hibi, K., Kihara, M., Toya, Y., Ochiai, H., Umemura, S., 1999. Angiotensinogen gene polymorphism near transcription start site and blood pressure. Role of a T-to-C transition at intron I. Hypertension 34, 430-434.

Iwai, N., Ohmichi, N., Nakamura, Y., Kinoshita, M., 1994a. DD genotype of the angiotensin-converting enzyme gene is a risk factor for left ventricular hypertrophy. Circulation 90, 2622-2628.

Iwai, N., Ohmichi, N., Nakamura, Y., Mitsunami, K., Kinoshita, M., 1994b. Molecular variants of the angiotensinogen gene and hypertension in a Japanese population. Hypertens. Res. 17, 117-121.

Jeunemaitre, X., Soubrier, F., Kotelevtsev, Y.V., Lifton, R.P., Williams, C.S., Charru, A., Hunt, S.C., Hopkins, P.N., Williams, R.R., Lalouel, J.M., Corvol, P., 1992. Molecular basis of human hypertension: role of angiotensinogen. Cell 71, 169-180.

Jeunemaitre, X., Inoue, I., William, C., Charru, A., Tichet, J., Powers, M., Sharma, A.M., Gimenez-Roqueplo, A.P., Hata, A., Corvol, P., Lalouel, J.M., 1997. Haplotypes of angiotensinogen in essential hypertension. Am. J. Hum. Genet. 60, 1448-1460.

Jian, M., Cao, X., Huang, J., Qi, J., Liu, G., Wang, J., Bai, D., Qiao, D., Zhao, J.F., Feng, S., Liu, L., 1996. Polymorphism of angiotensin I converting enzyme gene in the older Chinese: linked to ambulatory blood pressure levels and circadian blood pressure rhythm. Int. J. Cardiol. 55, 33-40.

Kamitani, A., Rakugi, H., Higaki, J., Ohishi, M., Shi, S.J., Takami, S., Nakata, Y., Higashino, Y., Fujii, K., Mikami, H., Miki, T., Ogihara, T., 1995. Enhanced predictability of myocardial infarction in Japanese by combined genotype analysis. Hypertension 25, 950-953.

Kario, K., Kanai, N., Saito, K., Nago, N., Takefumi, M., Shimada, K., 1996. Ischemic stroke and the gene for angiotensin-converting enzyme in Japanese hypertensives. Circulation 93, 1630-1633. 
Kato, N., Sugiyama, T., Morita, H., Kurihara, H., Yamori, Y., Yazaki, Y., 1999. Angiotensinogen gene and essential hypertension in the Japanese: extensive association study and meta-analysis on six reported studies. J. Hypertens. 17, 757-763.

Katsuya, T., Koike, G., Yee, T.W., Sharpe, N., Jackson, R., Norton, R., Horiuchi, M., Pratt, R.E., Dzau, V.J., MacMahon, S., 1995. Association of angiotensinogen gene T235 variant with increased risk of coronary heart disease. Lancet 345, 1600-1603.

Katsuya, T., Koike, G., Horiuchi, M., Yee, T., Dzau, V.J., MacMahon, S., 1996. T235 variant in angiotensinogen gene is also a risk factor for coronary heart disease. J. Hypertens. 14 (Suppl. 1), S13.

International Studies of Infarct (ISIS) Collaborators, Keavney, B., McKenzie, C., Parish, S., Palmer, A., Clark, S., Youngman, L., Delépine, M., Lathrop, M., Peto, R., Collin, R., 2000. Large-scale test of hypothesised associations between the angiotensin-converting-enzyme insertion/deletion polymorphism and myocardial infarction in about 5000 cases and 6000 controls. Lancet 355, 434-442.

Kiema, T.R., Kauma, H., Rantala, A.O., Lilja, M., Reunanen, A., Kesäniemi, Y.A., Savolainen, M.J., 1996. Variation at angiotensinconverting enzyme gene and angiotensinogen gene loci in relation to blood pressure. Hypertension 28, 1070-1075.

Kim, H.S., Krege, J.H., Kluckman, K.D., Hagaman, J.R., Hodgkin, J.B., Best, C.F., Jennette, J.C., Coffman, T.M., Maeda, N., Smithies, O., 1995. Genetic control of blood pressure and the angiotensinogen locus. Proc. Natl. Acad. Sci. U. S. A. 92, 2635-2739.

Kunz, R., Kreutz, R., Beige, J., Distler, A., Sharma, A.M., 1997. Association between the angiotensinogen 235T-variant and essential hypertension in whites. A systematic review and methodological appraisal. Hypertension 30, 1331-1337.

Kuznetsova, T., Staessen, J.A., Wang, J.G., Gasowski, J., Nikitin, Y., Ryabikov, A., Vlietinck, R., Fagard, R., 2000. Antihypertensive treatment modulates the association between the $D / I$ ACE gene polymorphism and left ventricular hypertrophy: a meta-analysis. J. Hum. Hypertens. 14, 447-454.

Lewis, E.J., Hunsicker, L.G., Bain, R.P., Rohde, R.P., 1993. The effect of angiotensin-converting enzyme inhibition on diabetic nephropathy. $\mathrm{N}$. Engl. J. Med. 329, 1456-1462.

MacKay, J.H., Arcuri, K.E., Goldberg, A.I., Snapinn, S.M., Sweet, C.S., 1996. Losartan and low-dose hydrochlorothiazide in patients with essential hypertension. A double-blind placebo-controlled trial of concomitant administration compared with individual components. Arch. Intern. Med. 156, 278-285.

Marian, A.J., Yu, Q.T., Workman, R., Greve, G., Roberts, R., 1993. Angiotensin-converting enzyme polymorphism in hypertrophic cardiomyopathy and sudden cardiac death. Lancet 342, 1085-1086.

Markus, H.S., Barley, J., Lunt, R., Bland, J.M., Jeffery, S., Carter, N.D., Brown, M.M., 1995. Angiotensin-converting enzyme gene deletion polymorphism. A new risk factor for lacunar stroke but not carotid atheroma. Stroke 26, 1329-1333.

Marre, M., Bernadet, P., Gallois, Y., Savagner, F., Guyene, T.T., Hallab, M., Cambien, F., Passa, P., Alhenc-Gelas, F., 1994. Relationships between angiotensin I-converting enzyme gene polymorphism, plasma levels, and diabetic retinal and renal complications. Diabetes 43, 384-388.

Marre, M., Jeunemaitre, X., Gallois, Y., Rodier, M., Chatellier, G., Sert, C., Dusselier, L., Kahal, Z., Chaillous, L., Halami, S., Muller, A., Sackmann, H., Bauduceau, B., Bled, F., Passa, P., Alhenc-Gelas, F., 1997. Contribution of genetic polymorphisms in the renin-angiotensin system to the development of renal complications in insulin-dependent diabetes. Génétique de la Néphropathie Diabétique (GENEDIAB) Study Group, J. Clin. Invest. 99, 1585-1595.

McKenzie, C.A., Julier, C., Forrester, T., McFarlane-Anderson, N., Keavney, B., Lathrop, G.M., Ratcliffe, P.J., Farrall, M., 1995. Segregation and linkage analysis of serum angiotensin I-converting enzyme levels: evidence for two quantitative-trait loci. Am. J. Hum. Genet. $57,1426-1435$

McLaughlin, K.J., Jagger, C., Small, M., Jardine, A.G., 1995. Effect of angiotensinogen gene T235 variant on the development of diabetic complications in type II diabetes mellitus. Lancet 346, 1160-1160.

Miyamoto, Y., Yoshimasa, T., Itoh, H., Igaki, T., Harada, M., Yamashita, J., Chun, T., Doi, K., Ishikawa, M., Hori, Y., Kuwahara, K., Ogawa, E., Inoue, M., Masuda, I., Saito, Y., Nakao, K., 1996. Association of angiotensin II type 1 receptor gene polymorphism with essential hypertension in Japanese. J. Hypertens. 14 (Suppl. 1), S29.

Morise, T., Takeuchi, Y., Takeda, R., 1994. Angiotensin-converting enzyme polymorphism and essential hypertension. Lancet 343, 125.

Müller, D.N., Bohlender, J., Hilgers, K.F., Dragun, D., Costerousse, O., Ménard, J., Luft, F.C., 1997. Vascular angiotensin-converting enzyme expression regulates local angiotensin II. Hypertension 29, 98-104.

Nakai, K., Itoh, C., Miura, Y., Hotta, K., Musha, T., Itoh, T., Miyakawa, T., Iwasaki, R., Hiramori, K., 1994. Deletion polymorphism of the angiotensin I-converting enzyme gene is associated with serum ACE concentration and increased risk for CAD in Japanese. Circulation 90, 2199-2202.

Nakauchi, Y., Suehiro, T., Yamamoto, M., Yasuoka, N., Ari, K., Kumon, Y., Hamashige, N., Hashimoto, K., 1996. Significance of angiotensin I-converting enzyme and angiotensin II type 1 receptor gene polymorphism as a risk factor for coronary heart disease. Atherosclerosis 125, $161-169$.

Nishiuma, S., Kario, K., Kayaba, K., Nagio, N., Shimada, K., Matsuo, T., Matsuo, M., 1995. Effect of the angiotensinogen gene $\mathrm{Met}^{235}-\mathrm{Thr}$ variant on blood pressure and other cardiovascular risk factors in two Japanese populations. J. Hypertens. 13, 717-722.

Nomura, H., Koni, I., Michishita, Y., Morise, T., Takeda, R., 1994. Angiotensin-converting enzyme gene polymorphism in haemodialysis patients. Lancet 343, 482-483.

O'Donnell, C.J., Lindpaintner, K., Larson, M.G., Rao, V.S., Ordovas, J.M., Schaefer, E.J., Myers, R.H., Levy, D., 1998. Evidence for association and genetic linkage of the angiotensin-converting enzyme locus with hypertension and blood pressure in men but not women in the Framingham Heart Study. Circulation 97, 1766-1772.

Ohishi, M., Fujii, K., Minamino, T., Higaki, J., Kamitani, A., Rakugi, H., Zhao, Y., Mikami, H., Miki, T., Ogihara, T., 1993. A potent genetic risk factor for restenosis. Nat. Genet. 5, 324-325.

Okamura, T., Miyazaki, M., Inagami, T., Toda, N., 1986. Vascular renin angiotensin system in two kidney, one clip hypertensive rats. Hypertension 8, 560-565.

Osterop, A.P.R.M., Kofflard, M.J.M., Sandkuijl, L.A., ten Cate, F.J., Krams, R., Schalekamp, M.A.D.H., Danser, A.H.J., 1998. AT 1 receptor $\mathrm{A} / \mathrm{C}^{1166}$ polymorphism contributes to cardiac hypertrophy in subjects with hypertrophic cardiomyopathy. Hypertension 32, 825830

Pfeffer, M.A., Braunwald, E., Moyé, L.A., Basta, L., Brown, E.J. Jr., Cuddy, T.E., Davis, B.R., Geltman, E.M., Goldman, S., Flaker, G.C., Klein, M., Lamas, G.A., Packer, M., Rouleau, J., Rouleau, J.L., Rutherford, J., Wertheimer, J.H., Hawkins, C.M., 1992. Effect of captopril on mortality and morbidity in patients with left ventricular dysfunction after myocardial infarction. N. Engl. J. Med. 327, 669677 , on behalf of the SAVE Investigators.

Poirier, O., Georges, J.L., Ricard, S., Arvelier, D., Ruidavets, J.B., Luc, G., Evans, A., Cambien, F., Tiret, L., 1998. New polymorphisms of the angiotensin II type 1 receptor gene and their associations with myocardial infarction and essential hypertension: the ECTIM study. J. Hypertens. 16, 1443-1447.

Pontremoli, R., Sofia, A., Tirotta, A., Ravera, M., Nicolella, C., Viazzi, F., Bezante, G.P., Borgia, L., Bobola, N., Ravazzalo, R., Sacchi, G., Deferrari, G., 1996. The deletion/insertion polymorphism of the angiotensin I-converting enzyme gene is associated with target organ damage in essential hypertension. J. Am. Soc. Nephrol. 7, 2550-2558.

Province, M.A., Boerwinkle, E., Chakravarti, A., Cooper, R., Fornage, M., Leoppert, M., Risch, N., Ranade, K., 2000. Lack of association of the angiotensinogen- 6 polymorphism with blood pressure levels in the comprehensive NHLBI Family Blood Pressure Program. J. Hypertens. $18,867-876$ 
Raynolds, M.V., Bristow, M.R., Bush, E.W., Abraham, W.T., Lowes, B.D., Zisman, L.S., Taft, C.S., Perryman, M.B., 1993. Angiotensinconverting enzyme DD genotype in patients with ischaemic or idiopathic dilated cardiomyopathy. Lancet 342, 1073-1075.

Rice, G.I., Foy, C.A., Grant, P.J., 1999. Angiotensin converting enzyme and angiotensin II type 1-receptor gene polymorphisms and risk of ischaemic heart disease. Cardiovasc. Res. 41, 746-753.

Rigat, B., Hubert, C., Alhenc-Gelas, F., Cambien, F., Corvol, P., Soubrier, F., 1990. An insertion/deletion polymorphism in the angiotensin I-converting enzyme gene accounting for half the variance of serum enzyme levels. J. Clin. Invest. 86, 1343-1346.

Rigat, B., Hubert, C., Corvol, P., Soubrier, F., 1992. PCR detection of the insertion/deletion polymorphism of the human angiotensin converting enzyme gene (DCP1) (dipeptidyl carboxypeptidase 1). Nucleic Acids Res. 20, 1433-1433.

Rotimi, C., Morrison, L., Cooper, R., Oyejide, C., Effiong, E., Lapido, M., Osotemihen, B., Ward, R., 1994. Angiotensinogen gene in human hypertension: lack of an association of the 235T allele among African Americans. Hypertension 24, 591-594.

Rotimi, C., Cooper, R., Ogunbiyi, O., Morrison, L., Lapido, M., Tewksbury, D., Ward, R., 1997. Hypertension, serum angiotensinogen, and molecular variants of the angiotensinogen gene among Nigerians. Circulation 95, 2348-2350.

Samani, N.J., Thompson, J.R., O'Toole, L., Channer, K., Woods, K.L., 1996. A meta-analysis of the association of the deletion allele of the angiotensin-converting enzyme with myocardial infarction. Circulation 94, 708-712.

Sato, N., Katsuya, T., Rakugi, H., Takami, S., Nakata, Y., Miki, T., Higaki, J., Ogihara, T., 1997. Association of variants in critical core promoter element of angiotensinogen gene with increased risk of essential hypertension in Japanese. Hypertension (Part 1) 30, 321-325.

The Diabetic Nephropathy Study Group, Schmidt, S., Schöne, N., Ritz, E., 1995. Association of ACE gene polymorphism and diabetic nephropathy? Kidney Int. 47, 1176-1181.

Schunkert, H., Dzau, V.J., Tang, S.S., Hirsch, A.T., Apstein, C.S., Lorell, B.H., 1990. Increased rat cardiac angiotensin converting enzyme activity and mRNA expression in pressure overload left ventricular hypertrophy: effects on coronary resistance, contractility and relaxation. J. Clin. Invest. 86, 1913-1920.

Schunkert, H., Hense, H.W., Holmer, S.R., Stender, M., Perz, S., Keil, U., Lorell, B.H., Riegger, G.A.J., 1994. Association between a deletion polymorphism of the angiotensin-converting-enzyme gene and left ventricular hypertrophy. N. Engl. J. Med. 330, 1634-1638.

Sealey, J.E., James, G.D., Laragh, J.H., 1995. The renin-angiotensin-aldosterone system for normal regulation of blood pressure and sodium and potassium homeostasis. In: Laragh, J.H., Brenner, B.M. (Eds.), Hypertension. Pathophysiology, Diagnosis and Management, vol. 2, Raven Press, New York, NY, USA, pp. 1763-1796.

Sharpe, N., Murphy, J., Smith, H., Hannon, S., 1988. Treatment of patients with symptomless left ventricular dysfunction after myocardial infarction. Lancet i, 255-259.

Sharpe, N., Smith, H., Murphy, J., Greaves, S., Hart, H., Gamble, G., 1991. Early prevention of left ventricular dysfunction after myocardial infarction with angiotensin-converting-enzyme inhibition. Lancet 337 , 872-876.

Smithies, O., 1997. A mouse view of hypertension. Hypertension 30, $1318-1324$

Staessen, J.A., Ginocchio, G., Wang, J.G., Saavedra, A.P., Soubrier, F., Vlietinck, R., Fagard, R., 1997a. Genetic variability in the reninangiotensin system: prevalence of alleles and genotypes. J. Cardiovasc. Risk 4, 401-422.

Staessen, J.A., Wang, J.G., Ginocchio, G., Petrov, V., Saavedra, A.P., Soubrier, F., Vlietinck, R., Fagard, R., 1997b. The deletion/insertion polymorphism of the converting-enzyme and cardiovascular-renal risk. J. Hypertens. 15, 1579-1592.

Staessen, J.A., Kuznetsova, T., Wang, J.G., Emelianov, D., Vlietinck, R.,
Fagard, R., 1999. M235T angiotensinogen gene polymorphism and cardiovascular renal risk. J. Hypertens. 17, 9-17.

Staessen, J.A., Wang, J.G., Brand, E., Barlassina, C., Bianchi, G., Cusi, D., Egbers, B., Fagard, R., Sharma, A.R., Soubrier, F., 2000. Association between blood pressure, hypertension and polymorphisms of the aldosterone synthase and $\alpha$-adducin genes in a Belgian population study. J. Mol. Med. 78, B8.

Takami, S., Katsuya, T., Rakugi, H., Sato, N., Nakata, Y., Kamitani, A., Miki, T., Higaki, J., Ogihara, T., 1998. Angiotensin II type 1 receptor gene polymorphism is associated with increase of left ventricular mass but not with hypertension. Am. J. Hypertens. 11, 316-321.

Takami, S., Imai, Y., Katsuya, T., Ohkubo, T., Tsuji, I., Nagai, K., Satoh, H., Hisamichi, S., Higaki, J., Ogihara, T., 2000. Gene polymorphism of the renin-angiotensin system associates with risk for lacunar infarctions: the Ohasama Study. Am. J. Hypertens. 13, 121-127.

Tamura, K., Umemura, S., Ishii, M., Tanimoto, K., Murakami, K., Fukamizu, A., 1994. Molecular mechanism of transcriptional activation of angiotensonigen gene by proximal promoter. J. Clin. Invest. 93, 1370-1379.

Tarnow, L., Cambien, F., Rossing, P., Nielsen, F.S., Hansen, B.V., Lecerf, L., Poirier, O., Danilov, S., Parving, H.H., 1995. Lack of relationship between an insertion/deletion polymorphism in the angiotensin I-converting enzyme gene and diabetic nephropathy and proliferative retinopathy in IDDM patients. Diabetes 44, 489-494.

Tarnow, L., Cambien, F., Rossing, P., Nielsen, F.S., Hansen, B.V., Ricard, S., Poirier, O., Parving, H.H., 1996. Angiotensin-II type 1 receptor gene polymorphism and diabetic microangiopathy. Nephrol. Dial. Transplant. 11, 1019-1023.

Tiret, L., Rigat, B., Visvikis, S., Breda, C., Corvol, P., Cambien, F., Soubrier, F., 1992. Evidence, from combined segregation and linkage analysis, that a variant of the angiotensin I-converting enzyme (ACE) gene controls plasma ACE levels. Am. J. Hum. Genet. 51, 197-205.

Tiret, L., Kee, F., Poirier, O., Nicaud, V., Lecerf, L., Evans, A., Cambou, J.P., Arveiler, D., Luc, G., Amouyel, P., Cambien, F., 1993. Deletion polymorphism in angiotensin-converting enzyme gene associated with parental history of myocardial infarction. Lancet 341, 991-992.

Tiret, L., Bonnardeaux, A., Poirier, O., Ricard, S., Marques-Vidal, P., Evans, A., Arveiler, D., Luc, G., Kee, F., Ducimetière, P., Soubrier, F., Cambien, F., 1994. Synergistic effects of angiotensin-converting enzyme and angiotensin-II type 1 receptor gene polymorphisms on risk of myocardial infarction. Lancet 344, 910-913.

CARDIGENE Group, Tiret, L., Mallet, C., Poirier, O., Nicaud, V., Millaire, A., Bouhour, J.B., Roizès, G., Desnos, M., Dorent, R., Schwartz, K., Cambien, F., Komajda, M., 2000. Lack of association between polymorphisms of eight candidate genes and idiopathic dilated cardiomyopathy. J. Am. Coll. Cardiol. 35, 29-35.

Tomino, Y., Makita, Y., Shike, T., Gohda, T., Haneda, M., Kikkawa, R., Watanabe, T., Baba, T., Yoshida, H., 1999. Relationship between polymorphism in the angiotensinogen, angiotensin-converting enzyme or angiotensin II receptor and renal progress in Japanese NIDDM patients. Nephron 82, 139-144.

Urata, H., Nishimura, H., Ganten, D., 1996. Chymase-dependent angiotensin II forming system in humans. Am. J. Hypertens. 9, 277-277.

van Geel, P.P., Pinto, Y.M., Voors, A.A., Buikema, H., Oosterga, M., Crijns, H.J.G.M., van Gilst, W.H., 2000. Angiotensin II type 1 receptor $\mathrm{A} 1166 \mathrm{C}$ gene polymorphism is associated with an increased response to angiotensin II in human arteries. Hypertension 35, 717721.

Villard, E., Tiret, L., Visvikis, S., Rakotovao, R., Cambien, F., Soubrier, F., 1996. Identification of new polymorphisms of the angiotensin I-converting enzyme (ACE) gene, and study of their relationship to plasma ACE levels by two-QTL segregation-linkage analysis. Am. J. Hum. Genet. 58, 1268-1278.

Wang, W.Y.S., Zee, R.Y.L., Morris, B.J., 1997. Association of angiotensin II type I receptor gene polymorphism with esential hypertension. Clin. Genet. 51, 31-34. 
Yamada, Y., Ichihara, S., Fujimura, T., Yokota, M., 1997. Lack of association of polymorphisms of the angiotensin converting enzyme and angiotensinogen genes with nonfamilial hypertrophic or dilated cardiomyopathy. Am. J. Hypertens. 10, 921-928.

Yanai, K., Nibu, Y., Murakami, K., Fukamizu, A., 1996. A cis-acting DNA element located between TATA box and transcription initiation site is critical in response to regulatory sequences in human angiotensinogen gene. J. Biol. Chem. 271, 15981-15986.

Yudkin, J.S., Andrès, C., Mohamed, A.V., Gould, M., Panahloo, A., Haines, A.P., Humphries, S., Talmud, P., 1997. The angiotensin-converting enzyme gene and the angiotensin II type I receptor gene as candidate genes for microalbuminuria. A study in non-diabetic and non-insulin dependent diabetic subjects. Arterioscler. Thromb. Vasc. Biol. 17, 2188-2191.

Zhang, X., Erdmann, J., Regitz-Zagrosek, V., Kürzinger, S., Hense, H.W., Schunkert, H., 2000. Evaluation of three polymorphisms in the promotor region of the angiotensin II type I receptor gene. J. Hypertens. 18, 267-272.

Zhao, Y.Y., Zhou, J., Narayanan, C.S., Cui, Y., Kumar, A., 1999. Role of $\mathrm{C} / \mathrm{A}$ polymorphism at -20 on the expression of human angiotensinogen gene. Hypertension 33, 108-115. 